ISSN 1392-3196 / e-ISSN 2335-8947

Zemdirbyste-Agriculture, vol. 101, No. 3 (2014), p. 243-248

DOI 10.13080/z-a.2014.101.031

\title{
The effect of different forms of nitrogen fertilizers on nitrogen leaching
}

\author{
Liudmila TRIPOLSKAJA, Ingrida VERBYLIENĖ \\ Vokè Branch, Lithuanian Research Centre for Agriculture and Forestry \\ Žalioji 2, Vilnius, Lithuania \\ E-mail: liudmila.tripolskaja@voke.lzi.lt
}

\begin{abstract}
The aim of the work was to evaluate the effect of different forms (granular or liquid) of nitrogen fertilizers on nitrate concentration and nitrogen leaching from a sandy loam Haplic Luvisol (LVh), to identify precipitation infiltration differences in fertilized and unfertilized soils. It was revealed that fertilization with nitrogen (on average $120 \mathrm{~kg} \mathrm{ha}^{-1} \mathrm{~N}$ ), compared to the unfertilized soil, increased the average annual nitrate concentration in leachate by $37.5-54.3 \%(P<0.05)$. Slightly higher nitrate concentration was revealed after application of liquid fertilizer UAN 32. Compared to unfertilized soil, the impact of fertilizers on the increase of nitrate concentration in leachate was significant during summer (by $6.2-40.4 \mathrm{mg} \mathrm{L}^{-1} \mathrm{NO}_{3} ; P<0.05$ ) and autumn (by $32.2-52.3 \mathrm{mg} \mathrm{L}^{-1} \mathrm{NO}_{3}$, or $49.8-80.8 \% ; P<0.05)$. Nitrogen leaching from nitrogen-fertilized soil increased by on average $6.3-9.5 \mathrm{~kg} \mathrm{ha}^{-1} \mathrm{~N}$ per year, as compared with the unfertilized soil. Compared with ammonium nitrate and liquid complex fertilizer Lyderis 9-9-9, significantly more nitrogen (by $2.7-3.2 \mathrm{~kg} \mathrm{ha}^{-1} \mathrm{~N} ; P<0.05$ ) was leached from the soil applied with liquid fertilizer UAN 32. An average of $6.0-8.9 \%$ of applied nitrogen fertilizer content was leached per year. Thicker and more vigorous crops formed in fertilized soil, this reduced the average rainfall infiltration by $13.7-16.2 \%$ per year and by $31.6-38.8 \%$ during summer period, compared with unfertilized soil. This reduced the overall nitrogen leaching losses resulting from application of fertilizers.
\end{abstract}

Key words: ammonium-N, granular fertilizers, Haplic Luvisol, liquid fertilizers, lysimeter, nitrate-N, urea-N.

\section{Introduction}

Comparative studies on the efficacy of granular and liquid nitrogen fertilizers generally suggest that their efficiency is similar if fertilizers are used at equal rates and at the same time, but different soil and climatic conditions may cause variations of their effects (Lubomir, 2003; Staugaitis et al., 2006). However, the difference in form of granular and liquid fertilizers makes application of liquid fertilizers more convenient and effective in the course of plant vegetation period. This increases utilisation rate of nutrients from fertilizers and reduces the leaching losses (Broschat, 1995).

In light-textured soils, an important criterion for the efficiency of fertilizers is leaching of nitrogen and other nutrients from arable soil layer. Nitrogen $(\mathrm{N})$ in fertilizer solutions is available mainly in three forms: ammonium-N, that has a positive electric charge (cation); nitrate-N, that has a negative electric charge (anion); urea-N, that is a non-charged molecule. These nitrogen compounds encounter a highly complex environment when they come in contact with the soil. The ammonium cation is adsorbed to the negatively charged clay particles and is slowly oxidized by soil bacteria to nitrate-N. The nitrate-N enters the soil, moves with the water and accumulates to a very high concentration at the boundary between the wet and dry soil zones. Urea, the non-charged molecule, is able to travel considerable distances in the soil with the moving water. Once in contact with the ubiquitous soil enzyme urease; however, this molecule is rapidly converted to carbon dioxide $\left(\mathrm{CO}_{2}\right)$ and ammonia (Schimel, Bennett, 2004; Kafkafi, Tarchitzky, 2011). As a result, nitrogen fertilizers of different chemical composition may have various effects on nitrogen leaching and environmental pollution. Experiments performed in England showed that under different climatic conditions nitrogen uptake and leaching from liquid and granular urea and ammonium nitrate varied (Readman et al., 2002). In one year, plants assimilated more nitrogen from liquid fertilizer, the next year no differences were observed. Only during one year of the three year period nitrogen leaching decreased after plant fertilization with liquid urea.

After application of nitrogen fertilizers nitrogen emissions may increase for a short period. The more $\mathrm{NO}_{3}$ ions are comprised in a nitrogen fertilizer, the higher are gaseous nitrogen losses compared with ammonium fertilizers. Several studies have shown that the emission of nitrogen compounds depended on the form of fertilizers. According to Linzmeier et al. (2001), compared to liquid fertilizers, the application in granulated form led to smaller $\mathrm{N}_{2} \mathrm{O}$ emission. Similar results on higher denitrification losses from liquid fertilizers were published by Paramasivam et al. (1998). The use of liquid nitrogen fertilizers is therefore superior to granular fertilizers because it reduces unproductive nitrogen losses and environmental pollution with biogenic elements. 
The aims of this work were: i) to determine the differences in nitrogen leaching from granular and liquid fertilizers, ii) to evaluate the effect of nitrogen fertilizer form (nitrate, ammonium, urea) on the concentration of nitrates and nitrogen leaching and iii) to determine the differences in precipitation infiltration in fertilized and unfertilized soil.

\section{Materials and methods}

Lysimeter experiments were conducted from March 2008 to February 2012 at the Voke Branch of the Lithuanian Institute of Agriculture (since 2010 Lithuanian Research Centre for Agriculture and Forestry). Round lysimeters $\left(\mathrm{n}=12\right.$, each covering $\left.1.75 \mathrm{~m}^{2}\right)$ were packed (0.6 m depth) with a sandy loam (sand - 2000 $63 \mu \mathrm{m}, 65.4 \%$, silt $-63-2 \mu \mathrm{m}, 29.7 \%$, clay $-<2 \mu \mathrm{m}$, $4.9 \%)$ Haplic Luvisol ( $L V h)$, to evaluate the leaching of nitrogen $(\mathrm{N})$. Agrochemical characteristics of the topsoil arable $(0-20 \mathrm{~cm})$ layer before the experiment were as follows: $\mathrm{pH}_{\mathrm{KCl}} 5.9$, available phosphorus - $245 \mathrm{mg}$ $\mathrm{kg}^{-1} \mathrm{P}_{2} \mathrm{O}_{5}$, potassium - $127 \mathrm{mg} \mathrm{kg} \mathrm{K}_{2}^{-1} \mathrm{O}$ (A-L method), organic carbon $\left(\mathrm{C}_{\text {org }}\right)-1.58 \%$ (dry combustion method, ISO 10694:1995).

The replicated (3) experimental design include the following treatments: i) control (without mineral fertilizers), ii) granular simple NPK fertilizers (ammonium nitrate, granular superphosphate, potassium chloride), iii) complex liquid fertilizer Lyderis 9-9-9, iv) liquid fertilizer ureaammonium nitrate 32 (UAN 32) and granular PK fertilizers.

Fertilizer characteristics. Ammonium nitrate $\left(\mathrm{NH}_{4} \mathrm{NO}_{3}\right)$ - granular nitrogen fertilizer $(34.7 \% \mathrm{~N})$, nitrogen is in the form of ammonium and nitrate ions; granular superphosphate $\left(\mathrm{Ca}\left(\mathrm{H}_{2} \mathrm{PO}_{4}\right)_{2} \times \mathrm{H}_{2} \mathrm{O}+\mathrm{CaSO}_{4}\right.$ $\left.\times 2 \mathrm{H}_{2} \mathrm{O}\right)$ has $19-20 \% \mathrm{P}_{2} \mathrm{O}_{5}$, potassium chloride $(\mathrm{KCl})-$ granular potassium fertilizer $\left(60 \% \mathrm{~K}_{2} \mathrm{O}\right)$; liquid fertilizer Lyderis 9-9-9 has 9.0\% amide and ammonium nitrogen, phosphorus and potassium, nutrient ratio is 9-9-9; liquid fertilizer UAN $32\left(\mathrm{CO}\left(\mathrm{NH}_{2}\right)_{2} \times \mathrm{nNH}_{4} \mathrm{NO}_{3}\right)$ has $32.0 \% \mathrm{~N}$ amide, nitrate and ammonium nitrogen. Changes in the leaching of nitrate and infiltration of precipitation due to application different mineral fertilizers were investigated in the segment barley (Hordeum vulgare L.) $\rightarrow$ potato (Solanum tuberosum L.). Before sowing, barley was fertilized with $\mathrm{N}_{120} \mathrm{P}_{120} \mathrm{~K}_{120}$, potatoes before planting with $\mathrm{N}_{120} \mathrm{P}_{120} \mathrm{~K}_{120}$.

Table 1. Temperature deviations $\left({ }^{\circ} \mathrm{C}\right)$ from the standard climate norm $(\mathrm{SCN})$ during the experimental period $(2008$ March-2012 February; data from Vilnius Meteorological Station)

\begin{tabular}{|c|c|c|c|c|c|c|c|c|}
\hline \multirow{3}{*}{ Month } & \multicolumn{8}{|c|}{ Hydrological year } \\
\hline & \multicolumn{2}{|c|}{$\begin{array}{l}\text { March } 2008- \\
\text { February } 2009 \\
\end{array}$} & \multicolumn{2}{|c|}{$\begin{array}{l}\text { March } 2009- \\
\text { February } 2010\end{array}$} & \multicolumn{2}{|c|}{$\begin{array}{l}\text { March 2010- } \\
\text { February 2011 }\end{array}$} & \multicolumn{2}{|c|}{$\begin{array}{l}\text { March } 2011- \\
\text { February } 2012 \\
\end{array}$} \\
\hline & $\begin{array}{l}\text { temperature } \\
{ }^{\circ} \mathrm{C}\end{array}$ & $\begin{array}{l}\text { deviations } \\
\text { from SCN }\end{array}$ & $\begin{array}{l}\text { temperature } \\
{ }^{\circ} \mathrm{C}\end{array}$ & $\begin{array}{l}\text { deviations } \\
\text { from SCN }\end{array}$ & $\begin{array}{c}\text { temperature } \\
{ }^{\circ} \mathrm{C}\end{array}$ & $\begin{array}{l}\text { deviations } \\
\text { from SCN }\end{array}$ & $\begin{array}{l}\text { temperature } \\
{ }^{\circ} \mathrm{C}\end{array}$ & $\begin{array}{l}\text { deviations } \\
\text { from SCN }\end{array}$ \\
\hline March & 1.8 & 1.3 & 0.5 & 1.8 & 0.2 & 1.5 & -0.2 & 1.1 \\
\hline April & 8.9 & 3.4 & 8.7 & 3.2 & 7.6 & 2.1 & 8.7 & 3.2 \\
\hline May & 11.4 & -0.9 & 12.4 & 0.1 & 14.0 & 1.7 & 12.9 & 0.6 \\
\hline June & 15.8 & 0.3 & 14.9 & -0.6 & 16.7 & 1.2 & 18.3 & 2.8 \\
\hline July & 17.8 & 1.2 & 18.0 & 1.4 & 21.8 & 5.2 & 19.6 & 3.0 \\
\hline August & 17.6 & 1.6 & 16.4 & 0.4 & 19.8 & 3.8 & 17.3 & 1.3 \\
\hline September & 11.9 & 0.5 & 13.6 & 2.2 & 11,5 & 0.1 & 13.3 & 1.9 \\
\hline October & 8.4 & 2.1 & 4.8 & -1.5 & 4.4 & -1.9 & 6.6 & 0.3 \\
\hline November & 2.3 & 1.3 & 3.3 & 2.3 & 3.7 & 2.7 & 2.9 & 1.9 \\
\hline December & -0.2 & 3.3 & -3.1 & 0.4 & -7.5 & -4.0 & 1.2 & 4.7 \\
\hline January & -3.8 & 2.5 & -10.4 & -4.1 & -3.3 & 3.0 & -3.9 & 2.4 \\
\hline February & -3.6 & 1.7 & -4.1 & 1.2 & -7.5 & -2.2 & -9.8 & -4.5 \\
\hline
\end{tabular}

Calculation of percolated water volume. On the territory of Lithuania hydrological year period runs from $1^{\text {st }}$ March to $28^{\text {th }}$ February (Lietuvos gamtine geografija, 2013). The duration of the seasons is: spring - from $1^{\text {st }}$ March to $31^{\text {st }}$ May, summer - from $1^{\text {st }}$ June until $31^{\text {st }}$ August, autumn - from $1^{\text {st }}$ September until $30^{\text {th }}$ November, winter - from $1^{\text {st }}$ December until $28^{\text {th }}$ February. Therefore, the amount of atmospheric precipitation percolated water was calculated from $1^{\text {st }}$ March of the current year to $28^{\text {th }}$ February of the following year (12 months), and the duration of the experiment was from $1^{\text {st }}$ March 2008 to $28^{\text {th }}$ February 2012. Percolated water volume was measured according to the intensity of atmospheric precipitation. Amount of leachate per month, season of the year and per year was calculated. Nitrate concentration in leachate $\left(\mathrm{NO}_{3} \mathrm{mg} \mathrm{L}^{-1}\right)$ was determined each month. The weighted $\mathrm{NO}_{3}$ concentrations of separate months, seasons of the year and each year were estimated. The weighted concentration was calculated according to the formula: $\mathrm{K}_{\text {weight }}=\left(\mathrm{K}_{1} \times \mathrm{V}_{1}+\mathrm{K}_{2} \times \mathrm{V}_{2}+\mathrm{K}_{3} \times \mathrm{V}_{3}\right) /\left(\mathrm{V}_{1}+\mathrm{V}_{2}\right.$ leachate of one lysimeter of a corresponding treatment (1, 2,3 - replications) for a certain period of time (month, season of a year), $\mathrm{V}_{1,2,3}$ - amount of percolated water $\mathrm{L} \mathrm{m}^{-2}$ of one lysimeter of a corresponding treatment for a certain period of time (month, season of a year). The concentration of nitrate $\left(\mathrm{mg} \mathrm{NO}_{3} \mathrm{~L}^{-1}\right)$ in the leachate was determined by the colorimetric method.

The obtained data were processed by the methods of variance and correlation regression analyses with program ANOVA and MS Excel.

Meteorological conditions of the experimental period. During the years of the experiment (March 2008-February 2012) meteorological conditions were characterized by major deviations from the standard climate norm (SCN). Air temperature of spring months throughout the whole experimental period (except for May 2009 and March 2012) was by $0.5-3.4^{\circ} \mathrm{C}$ higher than the climate norm (Table 1). The summer of 2010 was very warm; the temperature exceeded the climate norm by $1.2-5.2^{\circ} \mathrm{C}$. Temperature conditions of winter periods varied: in 2008-2009 air temperature during the winter months exceeded the SCN by $1.7-3.3^{\circ} \mathrm{C}$, in December 2011 and January 2012 - by $2.4-4.7^{\circ} \mathrm{C}$, while in December 2010 and February 2011, on the contrary, air temperature was by $4.0-2.2^{\circ} \mathrm{C}$ lower than the SCN. $+\mathrm{V}_{3}$ ), where $\mathrm{K}_{1,2,3}$ - nitrate concentration $\mathrm{mg} \mathrm{NO}_{3}{ }^{-} \mathrm{L}^{-1}$ in 
Regarding precipitation, the summer of 2010 can be distinguished by the rainfall, which was by 40
$131 \mathrm{~mm}$ above the SCN throughout the whole season. June and July of 2009 were also rainy (Table 2).

Table 2. Precipitation deviations (\%) from the standard climatic norm (SCN) during the experimental period (2008 March-20012 February; data from Vilnius Meteorological Station)

\begin{tabular}{|c|c|c|c|c|c|c|c|c|}
\hline \multirow{3}{*}{ Month } & \multicolumn{8}{|c|}{ Hydrological year } \\
\hline & \multicolumn{2}{|c|}{$\begin{array}{l}\text { March } 2008- \\
\text { February } 2009\end{array}$} & \multicolumn{2}{|c|}{$\begin{array}{l}\text { March } 2009- \\
\text { February } 2010\end{array}$} & \multicolumn{2}{|c|}{$\begin{array}{l}\text { March } 2010- \\
\text { February } 2011 \\
\end{array}$} & \multicolumn{2}{|c|}{$\begin{array}{l}\text { March } 2011- \\
\text { February } 2012 \\
\end{array}$} \\
\hline & $\begin{array}{l}\text { precipitation } \\
\mathrm{mm}\end{array}$ & $\begin{array}{c}\text { deviations } \\
\text { from } \\
\text { SCN }\end{array}$ & $\begin{array}{l}\text { precipitation } \\
\mathrm{mm}\end{array}$ & $\begin{array}{c}\text { deviations } \\
\text { from } \\
\mathrm{SCN}\end{array}$ & $\begin{array}{l}\text { precipitation } \\
\mathrm{mm}\end{array}$ & $\begin{array}{c}\text { deviations } \\
\text { from } \\
\text { SCN }\end{array}$ & $\begin{array}{l}\text { precipitation } \\
\mathrm{mm}\end{array}$ & $\begin{array}{c}\text { deviations } \\
\text { from } \\
\text { SCN }\end{array}$ \\
\hline March & 63 & 162 & 40 & 103 & 47 & 120 & 36 & 36 \\
\hline April & 62 & 138 & 6 & 13 & 37 & 82 & 69 & 70 \\
\hline May & 104 & 179 & 46 & 79 & 113 & 195 & 136 & 136 \\
\hline June & 69 & 90 & 129 & 168 & 142 & 184 & 53 & 53 \\
\hline July & 58 & 75 & 107 & 138 & 208 & 270 & 201 & 201 \\
\hline August & 55 & 71 & 68 & 88 & 117 & 151 & 131 & 131 \\
\hline September & 31 & 47 & 60 & 91 & 80 & 121 & 95.5 & 96 \\
\hline October & 60 & 115 & 109 & 210 & 42 & 81 & 27 & 27 \\
\hline November & 34 & 61 & 72 & 129 & 54 & 96 & 27 & 27 \\
\hline December & 42 & 82 & 70 & 137 & 56 & 110 & 83 & 90 \\
\hline January & 46 & 121 & 23 & 60 & 43 & 113 & 63 & 166 \\
\hline February & 28 & 88 & 44 & 138 & 37 & 116 & 41 & 128 \\
\hline
\end{tabular}

\section{Results and discussion}

Changes in precipitation filtration in soil due to mineral fertilization. According to the data of 2008-2012, depending on rainfall, its intensity and plant vigour, percolated water amount ranged from $193-221 \mathrm{~L} \mathrm{~m}^{-2}$ in 2008 to $368-492 \mathrm{~L} \mathrm{~m}^{-2}$ in 2010 and averaged $285.9-341.2 \mathrm{~L} \mathrm{~m}^{-2}$ over the study period (Table 3). Under climatic conditions of Lithuania, more intensive precipitation infiltration is observed in spring, autumn and winter. During the study period, more intense precipitation infiltration took place in spring - on average $117.2-120.0 \mathrm{~L} \mathrm{~m}^{-2}$, or $36.2-41.9 \%$ of the average annual precipitation got infiltrated. In autumn infiltration was slightly lower, percolated water amount was 81.6$91.7 \mathrm{~L} \mathrm{~m}^{-2}$, or $26.2-29.6 \%$ of the annual amount. During the study period, the lowest precipitation infiltration was observed in winter because, due to below-zero temperatures, for a period of time the soil was frozen and infiltration did not occur. Average winter infiltration amount was $12.6-13.7 \%$ of the annual precipitation, representing 35.2-48.2 $\mathrm{L} \mathrm{m}^{-2}$. The intense rainfall during the summer of 2009 and 2010 changed the average trends of precipitation infiltration and the average infiltration losses during this period amounted to $49.8-81.4 \mathrm{~L} \mathrm{~m}^{-2}$, or $18.2-23.1 \%$ of the annual precipitation content.

Table 3. The changes of infiltration of atmospheric precipitation as influenced by application of different forms of mineral fertilizers

\begin{tabular}{|c|c|c|c|c|c|c|}
\hline \multirow{2}{*}{ Treatment } & \multicolumn{4}{|c|}{ Season of year } & \multicolumn{2}{|c|}{ Mean per year } \\
\hline & spring & summer & autumn & winter & $\mathrm{L} \mathrm{m}^{-2}$ & $\%$ \\
\hline Control (without mineral fertilizers) & 120.0 & 81.4 & 91.7 & 48.2 & 341.2 & 100.0 \\
\hline Granular simple NPK fertilizers & 118.5 & 55.7 & 82.9 & 37.1 & 294.0 & 86.2 \\
\hline Liquid fertilizer Lyderis 9-9-9 & 117.2 & 52.8 & 85.6 & 38.9 & 294.5 & 86.3 \\
\hline Liquid fertilizer UAN 32 & 117.5 & 49.8 & 81.6 & 36.9 & 285.9 & 83.8 \\
\hline $\mathrm{LSD}_{05}$ & 7.72 & 19.40 & 4.83 & 12.21 & 6.17 & \\
\hline
\end{tabular}

Vigour of the cultivated crops also influenced the precipitation infiltration. The denser is the vegetation cover, the more moisture plants consume for transpiration, and more abundant plant root system increases the soil water absorption. Our studies have confirmed this inference. In unfertilized soil plants were poorer and precipitation infiltration was more intense. The average annual infiltration losses in unfertilized soil amounted to $341.2 \mathrm{~L} \mathrm{~m}^{-2}$. In soil treated with various fertilizers infiltration was by $13.8-16.2 \%$ lower. Form of fertilizers, i.e. liquid or granular, similarly reduced the infiltration; no statistically significant differences were observed $(P>0.05)$. The analysis of infiltration dynamics by seasons of the year clearly shows the influence of vegetation cover on its intensity. In summer, when the crops are formed, rainfall infiltration differences in fertilized and unfertilized soil reached 31.6-38.8\%. Infiltration differences were particularly apparent in the case of heavy rainfall. In unfertilized soil containing little available nutrients a poor crop cover forms and, therefore abundant precipitation increases infiltration more than in fertilized soil. Positive impact of vigorous vegetation cover on the reduction of rainfall percolation was noted by various scientists (Bellot et al., 1999; Muñoz-Carpena, 2008; Petersen, Stringham, 2008). During autumn and winter periods, as decomposition of plant residues incorporated into soil proceeds, precipitation infiltration in fertilized soil remained lower (6.7-11.0\% and $19.2-23.4 \%$, respectively) compared to unfertilized soil, but in spring the differences almost disappeared. Lower precipitation percolation in a denser crop cover reduces the leaching of chemical elements and the risk of environmental contamination. 
Effect of fertilizers on nitrogen leaching. Effect of fertilizers on nitrate concentration in leachate depends on the period duration after the application of fertilizers and fertilizer nitrogen form. Studies show that the fertilizers applied pre-sowing (the third ten-day period of April) had no significant influence on nitrate concentration in leachate in spring. The differences in concentration with the unfertilized treatment made up $2.6-9.5 \mathrm{mg} \mathrm{L}^{-1} \mathrm{NO}_{3}$ and were statistically insignificant $(P>0.05)$ (Table 4$)^{3}$. This effect is associated with the intensity of infiltration during spring months. In Lithuania, the most intensive spring infiltration takes place in March or April (44.2 and $48.9 \mathrm{~L} \mathrm{~m}^{-2}$, respectively), i.e. before the application of fertilizers. In May, the infiltration is significantly reduced making up 9.6 $\mathrm{L} \mathrm{m}^{-2}$ on average (Tripolskaja et al., 2012). Therefore, nitrogen applied immediately before sowing remains in the upper soil layer and nitrate concentrations in the leachate do not significantly increase. In spring, nitrogen leaching losses in fertilized and unfertilized soil did not significantly differ, making up $10.0-12.0 \mathrm{~kg} \mathrm{ha}^{-1}$ on average. As mentioned above, for a short period of time in spring nitrogen from fertilizers still does not reach the deeper layers of the soil, differences in plant density and vigour due to fertilization are still negligible. Therefore, precipitation infiltration in both fertilized and unfertilized soil proceeds similarly, and nitrogen leaching differences in spring are not significant.

Table 4. Effect of different forms of fertilizers on nitrogen $(\mathrm{N})$ leaching

\begin{tabular}{|c|c|c|c|c|c|c|}
\hline \multirow[b]{2}{*}{ Treatment } & \multicolumn{4}{|c|}{ Season } & \multicolumn{2}{|c|}{ Mean per year } \\
\hline & spring & summer & autumn & winter & $\begin{array}{c}\mathrm{mg} \mathrm{L}^{-1} \mathrm{NO}_{3} \text { or } \\
\mathrm{kg} \mathrm{ha}^{-1} \mathrm{~N}\end{array}$ & $\%$ \\
\hline \multicolumn{7}{|c|}{ Nitrate concentration $\mathrm{mg} \mathrm{L}^{-1} \mathrm{NO}_{3}^{-}$} \\
\hline Control (without mineral fertilizers) & 35.6 & 21.3 & 64.7 & 54.0 & 46.3 & 100 \\
\hline Granular simple NPK fertilizers & 38.2 & 40.4 & 108.9 & 65.4 & 67.0 & 144.7 \\
\hline Liquid fertilizer Lyderis 9-9-9 & 41.8 & 27.5 & 96.9 & 66.7 & 63.7 & 137.5 \\
\hline Liquid fertilizer UAN 32 & 45.1 & 36.3 & 117.0 & 60.6 & 71.4 & 154.3 \\
\hline $\mathrm{LSD}_{05}$ & 9.53 & 8.05 & 19.70 & 14.78 & 7.85 & \\
\hline \multicolumn{7}{|c|}{ Nitrogen $\mathrm{kg} \mathrm{ha}^{-1} \mathrm{~N}$} \\
\hline Control (without mineral fertilizers) & 10.0 & 3.9 & 13.4 & 8.7 & 36.1 & 100.0 \\
\hline Granular simple NPK fertilizers & 10.2 & 4.9 & 18.7 & 9.0 & 42.9 & 118.7 \\
\hline Liquid fertilizer Lyderis 9-9-9 & 11.1 & 3.3 & 18.7 & 9.3 & 42.4 & 117.3 \\
\hline Liquid fertilizer UAN 32 & 12.0 & 4.3 & 20.7 & 8.6 & 45.6 & 126.3 \\
\hline $\mathrm{LSD}_{05}$ & 2.45 & 3.06 & 3.54 & 2.01 & 1.41 & \\
\hline
\end{tabular}

During the summer, rainfall infiltration decreases, and during certain months it can cease completely. However, in recent decades, due to climate change, rainfall has substantially increased in July and August. This activates the infiltration and nitrogen leaching. Compared with the spring period, in summer nitrate concentrations in the leachate decreased by on average of $24.2-67.1 \%$, but the differences between fertilized and unfertilized soil increased and became statistically significant $(P<0.05)$. Significantly higher $\mathrm{NO}_{3}$ concentration in the leachate $(+40.4 \mathrm{mg}$ $\mathrm{L}^{-1} \mathrm{NO}_{3}$, or $89.7 \%$ ), compared to unfertilized soil, was recorded in soil fertilized with ammonium nitrate and UAN $32\left(+36.3 \mathrm{mg} \mathrm{L}^{-1} \mathrm{NO}_{3}\right.$, or $\left.70.2 \%\right)$. The concentration increased the least $\left(6.2 \mathrm{mg} \mathrm{L}^{-1} \mathrm{NO}_{3}\right)$ in leachate of soil fertilized with Lyderis 9-9-9 fertilizer, which contains only amide and ammonium forms of nitrogen. Despite significantly higher nitrate concentrations in the leachate, during the summer nitrogen leaching losses in unfertilized and fertilizer soil were similar $\left(3.3-4.9 \mathrm{~kg} \mathrm{ha}^{-1} \mathrm{~N}\right)$, the differences were statistically insignificant $(P>0.05)$. It is associated with the fact that in fertilized soil denser and more vigorous crops form, and it significantly reduces the precipitation infiltration, respectively reducing nitrogen leaching.

Substantially higher nitrate concentrations in the leachate from fertilized soil remained in autumn as well. After the plant yield is removed the moisture evaporation from the soil surface is reduced; autumn rainfall infiltration in arable soils intensifies. The mineralization of plant residues starts and it also increases mineral nitrogen concentration in soil. These factors lead to a more rapid nitrate leaching from the upper soil layer and increase of nitrate concentrations in the leachate of both fertilized and unfertilized soil. Compared to unfertilized soil, nitrate concentration in the leachate of fertilized soil in autumn was $32.2-52.3 \mathrm{mg} \mathrm{L}^{-1} \mathrm{NO}_{3}$ on average, or by $49.8-80.8 \%$ higher $(P<0.05)$. Slightly lower nitrate concentration was recorded in leachate of the soil fertilized with Lyderis 9-9-9, where nitrogen is in the form of amide and ammonium. The enhanced nitrogen leaching from fertilized soil in autumn resulted in higher nitrogen leaching losses because infiltration differences were not significant. It was determined that in autumn in fertilized soil nitrogen leaching was $18.7-20.7 \mathrm{~kg} \mathrm{ha}^{-1} \mathrm{~N}$, or 39.4$54.1 \%(P<0.05)$ on average, compared to unfertilized soil. Nitrogen fertilizer form (nitrate, ammonium or amide) did not affect nitrogen leaching losses $(P>0.05)$.

During winter period the nitrate concentration in the leachate was on average $54.0-66.7 \mathrm{mg} \mathrm{L}^{-1} \mathrm{NO}_{3}$. Eight to ten months after application of fertilizers, they no longer had any significant impact on the nitrate concentration in the leachate $(P>0.05)$, although it was still by $5.4-12.7 \mathrm{mg} \mathrm{L}^{-1} \mathrm{NO}_{3}$ higher compared with unfertilized soil. Small and statistically not essential differences of nitrate concentration and percolated water volume in unfertilized and fertilized soil determined approximately the same nitrogen leaching during the winter, which was on average $8.6-9.3 \mathrm{~kg} \mathrm{ha}^{-1} \mathrm{~N}$.

Summarized results of the whole study period (2008-2012) demonstrate that application of $120 \mathrm{~kg} \mathrm{ha}^{-1}$ $\mathrm{N}$ mineral fertilizers in sandy loam soil resulted in an increase in nitrogen leaching losses by on average of 6.3- 
$9.5 \mathrm{~kg} \mathrm{ha}^{-1} \mathrm{~N}$, or $17.3-26.3 \%$. It comprised $6.0-8.9 \%$ of nitrogen incorporated with mineral fertilizers. Nitrogen leaching losses from fertilizers depend on many factors, but especially on the hydrothermal conditions, fertilizer rates, and soil texture. Therefore, the literature sources present various data on nitrogen leaching losses from mineral fertilizers. According to Ghiberto et al. (2009), on average about $15 \%$ of the nitrogen content applied with nitrogen fertilizers is leached; they also state that the higher amount of leached nitrogen is native nitrogen and a minor quantity from nitrogen fertilizer. According to Adomaitis et al. (Management of agroecosystem components, 2010), application of $\mathrm{N}_{111} \mathrm{P}_{96} \mathrm{~K}_{96}$ on sandy loam Cambisol increased nitrate leaching by an average of $19.4 \mathrm{~kg} \mathrm{ha}^{-1} \mathrm{~N}$ compared to unfertilized soil, and twofold higher the rate of fertilizers increased nitrogen losses up to 46.3 .

Comparing forms of fertilizers, it should be noted that a greater impact on nitrogen losses resulted from nitrogen form and not from the form of fertilizer (granular or liquid). Significantly higher $(P<0.05)$ amount, compared with ammonium nitrate and complex fertilizer Lyderis 9-9-9, of nitrogen leached from fertilizer UAN 32, where nitrogen is in the form of amide, ammonium and nitrate. Forms of fertilizers had no significant influence on nitrate concentration. Application of nitrogen fertilizers, compared with unfertilized soil, increased the amount of nitrates in the percolated water by $17.4-25.1 \mathrm{mg} \mathrm{L}^{-1}$ $\mathrm{NO}_{3}(P<0.05)$, and slightly higher concentration was recorded after application of fertilizer UAN 32. After the tests on nitrogen leaching from the traditional nitrogen fertilizers (urea, ammonium sulphate, ammonium nitrate, calcium nitrate) and the slow-release nitrogen fertilizers Fernández-Escobar et al. (2004) stated that total nitrogen losses were higher when ammonium nitrate and calcium nitrate had been applied. Similar data was published by Zhou et al. (2006). They studied the leaching of nitrogen from nitrate fertilizer, ammonium fertilizer and urea fertilizer. It was determined that leaching losses of mineral nitrogen were higher when nitrate fertilizer had been used compared to urea or ammonium fertilizer.

Correlation analysis of precipitation amount and nitrogen leaching losses revealed that under Lithuanian climatic conditions nitrogen leaching was more associated not with the annual precipitation but with rainfall amount in autumn. The correlation between annual precipitation and nitrogen loss was moderate, coefficient of determination was only $R^{2}=0.38-0.57$; the correlation between autumn rainfall and nitrogen loss was very strong $\left(R^{2}=0.78-0.93 ; \mathrm{n}=12\right)$ (Table 5).

Table 5. Coefficient of correlation between nitrogen leaching $\left(\mathrm{kg} \mathrm{ha}^{-1} \mathrm{~N}\right)$ and precipitation amount (mm)

\begin{tabular}{|c|c|c|c|c|c|}
\hline Season & & $\begin{array}{l}\text { Without mineral } \\
\text { fertilizers }\end{array}$ & $\begin{array}{l}\text { Granular simple } \\
\text { NPK fertilizers }\end{array}$ & $\begin{array}{l}\text { Liquid fertilizer } \\
\text { Lyderis 9-9-9 }\end{array}$ & $\begin{array}{c}\text { Liquid fertilizer UAN } 32 \\
+ \text { granular PK }\end{array}$ \\
\hline \multirow{2}{*}{ Spring } & $R^{*}$ & 0.57 & 0.64 & 0.55 & 0.82 \\
\hline & $t_{R} \% * *$ & 94.7 & 97.3 & 93.7 & 99.9 \\
\hline \multirow{2}{*}{ Summer } & $R$ & 0.19 & 0.21 & 0.24 & 0.35 \\
\hline & $t_{R} \%$ & 43.8 & 50.0 & 52.0 & 74.2 \\
\hline \multirow{2}{*}{ Autumn } & $R$ & 0.88 & 0.95 & 0.91 & 0.96 \\
\hline & $t_{R} \%$ & 99.9 & 99.9 & 99.9 & 99.9 \\
\hline \multirow{2}{*}{ Winter } & $R$ & 0.86 & 0.83 & 0.90 & 0.70 \\
\hline & $t_{R} \%$ & 99.9 & 99.9 & 99.9 & 99.9 \\
\hline \multirow{2}{*}{ Per year } & $R$ & 0.75 & 0.62 & 0.75 & 0.62 \\
\hline & $t_{R} \%$ & 99.5 & 96.9 & 99.5 & 96.9 \\
\hline
\end{tabular}

* - correlation coefficient, $* *$ - significance of correlation coefficient

In autumn, $37.1-45.4 \%$ of the annual amount of nitrogen is leached, so the rainier is the autumn the higher nitrogen content is leached from the upper soil layer. The established pattern confirms scientists' recommendations to reduce the infiltration from agricultural soils through autumn period by cultivating cover crops (Vos, van der Putten, 2004; Köhler et al., 2006; Jayasundara et al., 2007).

\section{Conclusions}

1. Application of nitrogen fertilizers (on average $120 \mathrm{~kg} \mathrm{ha}^{-1} \mathrm{~N}$ ), compared to unfertilized soil, increased the average annual nitrate concentration in leachate by $17.4-25.1 \mathrm{mg} \mathrm{L}^{-1} \mathrm{NO}_{3}$, or $37.5-54.3 \%(P<0.05)$. Slightly higher $(P>0.05)$ nitrate concentration was recorded as fertilizer UAN 32 had been used. Compared to unfertilized soil, the effect of fertilizers on the increase of nitrate concentration in leachate was significant in summer (6.2-40.4 $\left.\mathrm{mg} \mathrm{L}^{-1} \mathrm{NO}_{3} ; P<0.05\right)$ and autumn (32.2-52.3 $\mathrm{mg} \mathrm{L}^{-1} \mathrm{NO}_{3}$, or $\left.49.8-80.8 \% ; P<0.05\right)$.

2. Compared to unfertilized soil, nitrogen leaching resulting from the use of nitrogen fertilizers increased by on average $6.3-9.5 \mathrm{~kg} \mathrm{ha}^{-1} \mathrm{~N}$ during the year.
Significantly higher nitrogen content $\left(+2.7-3.2 \mathrm{~kg} \mathrm{ha}^{-1} \mathrm{~N}\right.$; $P<0.05)$ leached after the use of liquid fertilizer UAN 32 compared with ammonium nitrate and liquid complex fertilizer Lyderis 9-9-9.

3. Application of medium rates of mineral nitrogen fertilizers $\left(120 \mathrm{~kg} \mathrm{ha}^{-1} \mathrm{~N}\right)$ in sandy loam Haplic Luvisol resulted in leaching of $6.0-8.9 \% \mathrm{~N}$ of the fertilizers used.

4. In fertilized soil, denser and more vigorous crops formed compared with unfertilized soil and that reduced annual precipitation infiltration by on average $13.7-16.2 \%$ and even up to $31.6-38.8 \%$ in summer. This reduced nitrogen leaching losses resulting from the use of nitrogen fertilizers.

\section{Acknowledgements}

The paper presents research findings, obtained through the long-term research programme "Productivity and sustainability of agricultural and forest soils".

Received 19122012

Accepted 27052014 


\section{References}

Bellot J.,Sanchez J. R., Chirino E., Hernandez N., Abdelli F., Martinez J. M. 1999. Effect of different vegetation type cover on the soil water balance in semi-arid areas of South Eastern Spain. Physics and Chemistry of the Earth, Part B: Hydrologv. Oceans and Atmosphere. 24 (4): 353-357 http://dx.doi.org/10.1016/S1464-1909(99)00013-1

Broschat T. K. 1995. Nitrate, phosphate, and potassium leaching from conteiner-grown plants fertilized by several methods. HortScience, 30 (1): 74-77

Fernández-Escobar R., Benlloch M., Herrera E., GarcíaNovelo E. 2004. Effect of traditional and slow-release N fertilizers on growth of olive nursery plants and $\mathrm{N}$ losses by leaching. Scientia Horticulturae, 101 (1-2): 39-49 http://dx.doi.org/10.1016/j.scienta.2003.09.008

Ghiberto P. J., Libardi P. L., Brito A. S., Trivelin P. C. O. 2009. Leaching of nutrients from a sugarcane crop growing on an Ultisol in Brazil. Agricultural Water Management, 96 (10): 1443-1448 http://dx.doi.org/10.1016/j.agwat.2009.04.020

Jayasundara S., Wagner-Riddle C., Parkin G., von Bertoldi P., Warland J., Kay B., Voroney P. 2007. Minimizing nitrogen losses from a corn-soybean-winter wheat rotation with best management practices. Nutrient Cycling in Agroecosvstems. 79 (2): 141-159 http://dx.doi.org/10.1007/s10705-007-9103-9

Kafkafi U., Tarchitzky J. A. 2011. Tool for efficient fertilizer and water management. Paris, France, $138 \mathrm{p}$.

Köhler K., Duynisveld W. H. M., Böttcher J. 2006. Nitrogen fertilization and nitrate leaching into groundwater on arable sandy soils. Journal of Plant Nutrition and Soil Science. 169 (2): 185-195 http://dx.doi.org/10.1002/jpln.200521765

Lietuvos gamtinė geografija. 2013 / compiled by Eidukevičienė M. Klaipeda University, 331 p. (in Lithuanian)

Linzmeier W., Gutser R., Schmidhalter U. 2001. Nitrous oxide emission from soil and from a nitrogen-15 labelled fertilizer with the new nitrification inhibitor 3,4-dimethylpyrazole. Biology and Fertility of Soil, 34: 103-108 http://dx.doi.org/10.1007/s003740100383

Lubomir H. 2003. Interactive effect of irrigation and fertilization on the quality of apples. Journal of Applied Horticulture, 5: $3-6$
Management of agroecosystem components. Results of longterm agrochemical experiments. 2010 / compiled by Tripolskaja L. et al. Lithuanian Research Centre for Agriculture and Forestry, 568 p. (in Lithuanian)

Muñoz-Carpena R., Ritter A., Bosch D. D., Schaffer B., Potter T. L. 2008. Summer cover crop impacts on soil percolation and nitrogen leaching from a winter corn field. Agricultural Water Management. 95 (6): 633-644 http://dx.doi.org/10.1016/j.agwat.2008.01.005

Paramasivam S., Alva A., Prakash O. 1998. Denitrification from sandy soils trested with liquidd or dry granular nitrogen form. Soil Science. 163 (9): 686-693 http://dx.doi.org/10.1097/00010694-199809000-00002

Petersen S. L., Stringham T. K. 2008. Infiltration, runoff, and sediment yield in response to western juniper encroachment in Southeast Oregon. Rangeland Ecology and Management, 61 (1): 74-81 http://dx.doi.org/10.2111/07-070R.1

Readman R. J., Beckwith C. P., Kettlewell P. S. 2002. Effects of spray application of urea fertilizer at stem extension on winter wheat: N recovery and nitrate leaching. The Journal of Agricultural Science, 139: 11-25

Schimel J. P., Bennett J. 2004. Nitrogen mineralization: challenges of a changing paradigm. Ecology, 85 (3): 591-602 <http:// dx.doi.org/10.1890/03-8002> [accessed 0303 2014]

Staugaitis G., Kučinskas J., Petrauskienė R., Dalangauskienė A. 2006. Effect of fertilizer on early potatoes. Sodininkyste ir daržininkystè, 25: 36-41 (in Lithuanian)

Tripolskaja L., Verbyliene I., Marcinkonis S., Razukas A., Baksiene E., Romanovskaja D. 2012. The changes of the filtration of precipitation in soil in southeastern Lithuania under the influence of climate conditions. Journal of Food, Agriculture and Environment, 10 (3-4): 132-136

Vos J., van der Putten P. E. L. 2004. Nutrient cycling in a cropping system with potato, spring wheat, sugar beet, oats and nitrogen catch crops. II. Effect of catch crops on nitrate leaching in autumn and winter. Nutrient Cycling in Agroecosvstems. 70 (1): 23-31

http://dx.doi.org/10.1023/B:FRES.0000049358.24431.0d

Zhou J.-B., Xi J.-G., Chen Z.-J., Li Sh.-X. 2006. Leaching and transformation of nitrogen fertilizers in soil after application of $\mathrm{N}$ with irrigation: a soil column method. Pedosphere. 16 (2): 245-252 http://dx.doi.org/10.1016/S1002-0160(06)60050-7

ISSN 1392-3196 / e-ISSN 2335-8947

Zemdirbyste-Agriculture, vol. 101, No. 3 (2014), p. 243-248

DOI 10.13080/z-a.2014.101.031

\title{
Azoto trąšų skirtingų formų įtaka azoto išplovimui
}

\author{
L. Tripolskaja, I. Verbylienè \\ Lietuvos agrarinių ir miškų mokslų centro Vokès filialas
}

\section{Santrauka}

Tyrimo tikslas - ịvertinti ịvairių pavidalų (granuliuotų ir skystụjų) azoto trąšų ịtaką nitratų koncentracijai bei azoto išplovimui iš priesmèlio išplautžemio (IDp) ir nustatyti kritulių filtracijos skirtumus tręštame bei netręštame dirvožemyje. Nustatyta, kad tręšimas azoto trąšomis (vidutiniškai $120 \mathrm{~kg} \mathrm{ha}^{-1} \mathrm{~N}$ ), palyginus su netręštu dirvožemiu, vidutinę metine nitratų koncentraciją filtrate padidino 37,5-54,3\% $(P<0,05)$. Šiek tiek didesnè nitratų koncentracija filtrate buvo patręšus skystosiomis trąšomis KAS 32. Trąšų ịtaka nitratų koncentracijos padidejjimui buvo esminè vasaros $\left(6,2-40,4 \mathrm{mg} \mathrm{L}^{-1} \mathrm{NO}_{3} ; P<0,05\right)$ ir rudens $\left(32,2-52,3 \mathrm{mg} \mathrm{L}^{-1} \mathrm{NO}_{3}\right.$, arba 49,8-80,8 \%; $\left.P<0,05\right)$ laikotarpiais. Azoto išplovimas dèl azoto trąšų panaudojimo, palyginus su netręštu dirvožemiu, per metus padidejo vidutiniškai 6,3-9,5 kg ha-1 N. Palyginus su amonio salietra ir skystosiomis kompleksinèmis trąšomis Lyderis 9-9-9, esmingai daugiau $\left(2,7-3,2 \mathrm{~kg} \mathrm{ha}^{-1} \mathrm{~N} ; P<0,05\right)$ azoto išplauta iš skystuju trąšu KAS 32. Per metus išplauta vidutiniškai 6,0 8,9 \% su trąšomis ịterpto azoto. Mineralinėmis trąšomis tręštame dirvožemyje, palyginus su netręštu, susiformuoja tankesnis ir vešlesnis augalų pasėlis, dèl to kritulių filtracija per metus sumažèjo vidutiniškai 13,7-16,2 \%, o vasaros laikotarpiu - 31,6-38,8 \%. Tai sumažina azoto išplovimo nuostolius dèl trąšų panaudojimo.

Reikšminiai žodžiai: amidinis azotas, amonio azotas, granuliuotos trąšos, lizimetras, nitratinis azotas, skystosios trąšos, priesmèlio išplautžemis. 